\title{
Monoclonal antibody (Y1/82A) with specificity towards peripheral blood monocytes and tissue macrophages
}

\author{
F R DAVEY,* JACQUELINE L CORDELL, WENDY N ERBER, \\ KAREN A F PULFORD, K C GATTER, D Y MASON \\ From the *Department of Pathology, SUNY Health Science Center, Syracuse, New York, USA, and the \\ Nuffield Department of Pathology, John Radcliffe Hospital, Oxford
}

SUMMARY A new monoclonal antibody, Y1/82A, was raised against phytohaemagglutinin activated peripheral blood mononuclear cells. Using an immunohistochemical technique it was shown that $\mathrm{Yl} /$ 82A reacts against peripheral blood and bone marrow monocytes and resident macrophages from essentially all human tissues. Y1/82A bound to determinants present in leukaemic cells from patients with acute myelomonocytic leukaemia and acute monocytic leukaemia, but not to neoplastic cells from patients with malignant lymphoproliferative disorders or malignant epithelial tumours. Y1/82A failed to react with other cell types, with the exception of osteoclasts and megakaryocytes. Analysis by Western blotting showed that the antigen detected by antibody Y1/82A was associated with intracellular granules in macrophages.

Monoclonal antibody Y1/82A may be useful in the diagnosis of monocytic leukaemias and histiocytic neoplasms and in the identification of macrophages in tissues from various inflammatory and neoplastic conditions.

The monocyte-macrophage system is regarded as a network of specialised phagocytic cells which are widely scattered throughout the body.' These cells include peripheral blood monocytes, Kupffer cells of the liver, microglial cells of the brain, macrophages of lymph node and spleen, and fixed tissue macrophages in various other human tissues. Cells of the monocytemacrophage system, however, do not include nonlymphoid mononuclear cells known as dendritic cells. ${ }^{2}$ There is evidence that peripheral blood monocytes originate from bone marrow precursor cells ${ }^{3}$ and that tissue macrophages are derived from circulating monocytes. ${ }^{4}$ Bone marrow precursor cells therefore serve as the cells of origin for peripheral blood monocytes and tissue macrophages.

Cells of the monocyte-macrophage system are heterogeneous in terms of their morphology, cytochemistry, function and surface determinants. ${ }^{156}$ As promonocytes mature into monocytes and then into tissue macrophages they increase in size. The ratio of the nucleus to that of the cytoplasm decreases and the number of lysosomes and IgG receptors increases. Functionally, mature macrophages have greater ability to undergo phagocytosis and lymphocyte interaction than the less mature monocyte. ' Furthermore, populations of resident macrophages in lymphoid tissues appear to differ from each other: resident macrophages thought to be accessory cells of the $T$ cell immune response can be differentiated from accessory cells of the B cell immune response on the basis of different cellular determinants. ${ }^{5}$

Various morphological, cytochemical, and immunological techniques have been used to identify cells of the monocyte-macrophage system..$^{7-9}$ Among these techniques immunocytochemical labelling with monoclonal antibodies is one of the most sensitive and specific for identifying monocytes and tissue macrophages in non-neoplastic and neoplastic disorders. ${ }^{10}$ Numerous monoclonal antibodies have been raised against cells of the monocyte-macrophage system ${ }^{6-15}$ but most of these react only with subpopulations of cells in the monocyte-macrophage system. Furthermore, many monoclonal antibodies raised against cells of the monocyte-macrophage system also react with determinants found on cells belonging to other cellular systems. $^{10}$

In this respect we describe our experience with a new monoclonal antibody (Y1/28A) raised against phyto- 
hemagglutinin activated peripheral blood mononuclear cells. Using an immunohistochemical technique, we showed that this monoclonal antibody reacts with peripheral blood monocytes and a range of tissue macrophages from patients with non-neoplastic and neoplastic disorders.

\section{Material and methods}

Blocks of fresh tissue were obtained from the histopathology department of the John Radcliffe Hospital at necropsy or at the time of surgical resection and were immediately snap frozen in liquid nitrogen and stored at $-70^{\circ} \mathrm{C}$ until use. Tissues sampled from patients without neoplastic disorders included three lymph nodes with reactive hyperplasia, two sections of liver, and one section each of thymus, tonsil, spleen, liver, colon, kidney, heart, brain, striated muscle, thyroid, lung and skin. Tissues sampled from patients with neoplastic diseases included eight cases of non-Hodgkin's lymphoma, five cases of Hodgkin's lymphoma, six cases of squamous cell carcinoma of the bronchus, and one case of adenocarcinoma of the breast.

Cryostat sections $(6 \mu \mathrm{m})$ were prepared from these frozen tissues and stored (wrapped in aluminium foil) at $-20^{\circ} \mathrm{C}$ until staining.

Samples of peripheral blood and bone marrow were obtained from patients attending the haematology department of the John Radcliffe Hospital. The samples were drawn into ethylene diamine tetra-acetic acid or heparin anticoagulant and either push films or cytocentrifuge films of mononuclear cells separated on Triosil-Ficoll were prepared. ${ }^{16}$ Ten peripheral blood and four bone marrow samples were obtained from subjects without a haematological malignancy, and peripheral blood smears, as well as one of bone marrow film were received from those with either acute myelomonocytic leukaemia or acute monocytic leukaemia.

\section{PREPARATION OF ANTIGEN}

Peripheral blood from a healthy subject was collected in heparinised tubes. The mononuclear cells were separated from other blood elements by centrifugation on Triosil-Ficoll (Lymphoprep-Nyegaard and Company, Oslo). Mononuclear cells were removed from the interphase, washed, and resuspended in RPMI-1640 tissue culture medium at a concentration of $1 \times 10^{6} / \mu \mathrm{l}$. Mononuclear cells were then incubated with a 1/200 dilution (one phial reconstituted with $5 \mathrm{ml}$ of distilled water) of phytohaemagglutinin (PHA) (Flow Laboratories). After three days PHA stimulated blasts were washed once in phosphate buffered saline (PBS) and then resuspended in PBS at appropriate concentrations.

PRODUCTION OF MONOCLONAL ANTIBODY

A BALB/c mouse was immunised with an intraperitoneal injection of $1 \times 10^{6}$ PHA stimulated blasts. This was followed by an intraperitoneal injection of $2 \times 10^{6}$ and $5 \times 10^{6}$ PHA stimulated blasts after intervals of 10 days and four weeks, respectively. Three days after an intravenous injection of $1.5 \times 10^{6}$ PHA stimulated blasts spleen cells from the mouse ( 1.8 $\times 10^{8}$ ) were fused with $1.8 \times 10^{7}$ cells from the NS-1 myeloma cell line. ${ }^{17}$ After 14 days the cultures were inspected for growth and the supernatant fluid was screened for specific reactivity on cryostat sections of tonsil using the APAAP immunoalkaline phosphatase technique. ${ }^{18}$ The clone Y1/28A, which selectively stained germinal centre macrophages, was then isolated by standard cloning techniques and established in long term tissue culture. In all experiments antibody Y1/82A was used in the form of spent tissue culture supernatant.

\section{IMMUNOCHEMICAL LABELLING}

Frozen tissue sections $(6 \mu \mathrm{m})$ and blood and bone marrow films were labelled using the APAAP immunoalkaline phosphatase technique. ${ }^{18} 19$ Slides were fixed before APAAP staining in acetone (sections and cytocentrifuged preparations) or acetone:methanol. ${ }^{19}$

\section{IMMUNOFLUORESCENCE ANALYSIS}

Peripheral blood monocytes, granulocytes, and lymphocytes were analysed for expression of the Y1/82A determinant by indirect immunofluorescence using flow cytometry. Aliquots of normal peripheral blood mononuclear cells were incubated for $\mathbf{3 0}$ minutes with antibody Y1/82A at doubling dilutions in PBS from $1 / 5$ through $1 / 80$. Lymphocytes, monocytes, and granulocytes were analysed separately by gating on forward and right $\left(90^{\circ}\right)$ angle light scatter.

BIOCHEMICAL ANALYSIS OF THE DETERMINANT RECOGNISED BY Y $1 / 82 A$

Normal human spleen tissue was solubilised in a solution of $10 \%$ Brij (2 parts Brij 99:1 part 96, Sigma Chemical Co) as described by Dalchau and Fabre. ${ }^{20}$ The lysate was then centrifuged at $70000 \times g$ for 30 minutes at $4^{\circ} \mathrm{C}$. Samples of both the supernatant and the pellet were dotted on to nitrocellulose paper and allowed to dry. Aliquots of the supernatant were then run under both reducing and non-reducing conditions in a $10 \%$ polyacrylamide slab gel in the presence of sodium dodecyl sulphate. ${ }^{21}$ Proteins were blotted overnight on to nitrocellulose membranes as previously described..$^{22}$ After blocking with $3 \%$ bovine serum albumin (BSA) both the dot blots and the Western blots were immunostained using the APAAP technique. ${ }^{18}$ The molecular weights of the immunostained bands were established by comparison with molecular weight standards stained with fast green. ${ }^{23}$ 
Results

SAMPLES FROM PATIENTS WITHOUT NEOPLASTIC DISORDERS

Examination of lymphoid tissue showed a positive reaction in many types of tissue macrophages (table 1 ). In lymph nodes this included macrophages in the subcapsular and medullary sinuses, macrophages in germinal centres, mantle zones, and interfollicular areas (fig 1). Lymphocytes, endothelial cells, and dendritic reticulum cells were unreactive. In the thymus, cortical and medullary macrophages were positive, but cortical and medullary thymocytes and thymic epithelial cells were negative. There was an intense staining reaction of the macrophages of the splenic cords (fig 2). A few macrophages were present in germinal centres as well as around small arteries and capillaries.

Resident tissue macrophages in many non-lymphoid tissues were also reactive with monoclonal antibody Y1/82A. Kupffer cells and periportal macrophages of the liver (fig 3), interstitial macrophages, and rare glomerular macrophages of the kidney, microglia cells, and perivascular macrophages in the brain, as well as fixed macrophages of colon, lung, heart, skin, striated muscle and thyroid were also all positive for monoclonal antibody Y1/82A. No other cells from these tissues were positive. In the lung, macrophages in the alveolar spaces (but not the alveolar walls) were positive (fig 4).

In peripheral blood smears monocytes showed strong granular cytoplasmic labelling (table 1, fig 5) with monoclonal antibody $\mathrm{Y} 1 / 82 \mathrm{~A}$. The number of positive granules varied considerably between individual monocytes; no evidence of surface membrane labelling was seen. Lymphocytes, neutrophils, and eosinophils were negative, with the exception of occasional blood smears in which some neutrophils

Table 1 Distribution of $Y 1 / 82 \mathrm{~A}$ antigen in peripheral blood and tissues from patients with non-neoplastic disorders

\begin{tabular}{|c|c|}
\hline Tissues & Labelling with monoclonal antibody $Y 1 / 82 A$ \\
\hline Peripheral blood & Monocytes \\
\hline Bone marrow & $\begin{array}{l}\text { Monocytes, tissue macrophages, } \\
\text { megakaryocytes, osteoclasts }\end{array}$ \\
\hline Lymph node & $\begin{array}{l}\text { Sinus macrophages, germinal centre } \\
\text { macrophages, mantle zone macrophages, } \\
\text { interfollicular macrophages }\end{array}$ \\
\hline Tonsil & $\begin{array}{l}\text { Germinal centre macrophages, interfollicular } \\
\text { macrophages }\end{array}$ \\
\hline $\begin{array}{l}\text { Thymus } \\
\text { Spleen }\end{array}$ & $\begin{array}{l}\text { Cortical macrophages, medullary macrophages } \\
\text { Germinal centre macrophages, cordal } \\
\text { macrophages, periarterial macrophages, } \\
\text { pericapillary macrophages }\end{array}$ \\
\hline Liver & Kupffer cells, periportal macrophages \\
\hline Kidney & $\begin{array}{l}\text { Interstitial macrophages, rare glomerular } \\
\text { macrophage }\end{array}$ \\
\hline Colon & Macrophages in lamina propria \\
\hline Lung & $\begin{array}{l}\text { Peribronchial macrophages, alveolar space } \\
\text { macrophages }\end{array}$ \\
\hline Heart & Perivascular and interstitial macrophages \\
\hline Brain & Microglial and perivascular macrophages \\
\hline Skin & Dermal macrophages \\
\hline Striated muscle & Interstitial macrophages \\
\hline Thyroid & Rare interstitial macrophages \\
\hline
\end{tabular}

were weakly labelled. In the bone marrow smears strong staining of macrophages and monocytes was observed. Osteoclasts and megakarocytes exhibited an intense staining reaction. All other cells were negative.

\section{SAMPLES FROM PATIENTS WITH NEOPLASTIC DISORDERS}

The reactions of $\mathrm{Y} 1 / 82 \mathrm{~A}$ on samples from patients with neoplastic disorders are summarised in table 2 . Leukaemic cells from patients with acute myelomonocytic leukaemia and acute monocytic leukaemia were clearly positive (fig 6). In contrast, neoplastic cells from patients with non-Hodgkin's lymphoma, Hodgkin's disease, squamous cell carcinoma of the bronchus and adenocarcinoma of the breast were entirely negative. Groups of neoplastic cells, however, were often associated with large numbers of positively stained macrophages. Focal areas of acute and chronic inflammation often accompanied the presence of the tumour cells and in these areas macrophages were intensely stained.

\section{IMMUNOFLUORESCENCE ANALYSIS}

Flow cytofluorographic analysis showed no membrane staining of granulocytes and lymphocytes with Y1/82A at any dilution. Membrane labelling of small numbers of monocytes $(<3 \%)$ was observed but only at the lowest dilutions tested (1/5 and $1 / 10)$.

\section{BIOCHEMICAL ANALYSIS OF THE Y $1 / 82 A$}

\section{DETERMINANT}

Although the dot blotting experiments showed strongly immunoreactive $\mathrm{Y} 1 / 82 \mathrm{~A}$ antigen remaining in the high speed pellet, a weaker reaction was also observed with the supernatant.

Numerous attempts were made with the Western blotting technique to determine the molecular weight of the molecule(s) detected by Y1/82A. In some experiments a weak reaction was obtained against a reduced band, migrating with a molecular weight of about $45000 \mathrm{Kd}$ but this was not a consistently reproducible result.

\section{Discussion}

This study has shown that the monoclonal antibody Y1/82A raised against activated mononuclear cells reacts with a cytoplasmic determinant present in a very wide spectrum of cells from the monocytemacrophage system. These include peripheral blood and bone marrow monocytes as well as specialised tissue macrophages of the liver, spleen, lung, brain and skin. As some of these macrophages are in areas of inflammation or juxtaposed to tumour cells we can assume that many are activated. It seems that the Y1/82A antigen is therefore present in cells of the monocyte-macrophage system, both at different stages of maturation and also in various stages of activation.

Y1/82A clearly differentiates between cells of the 


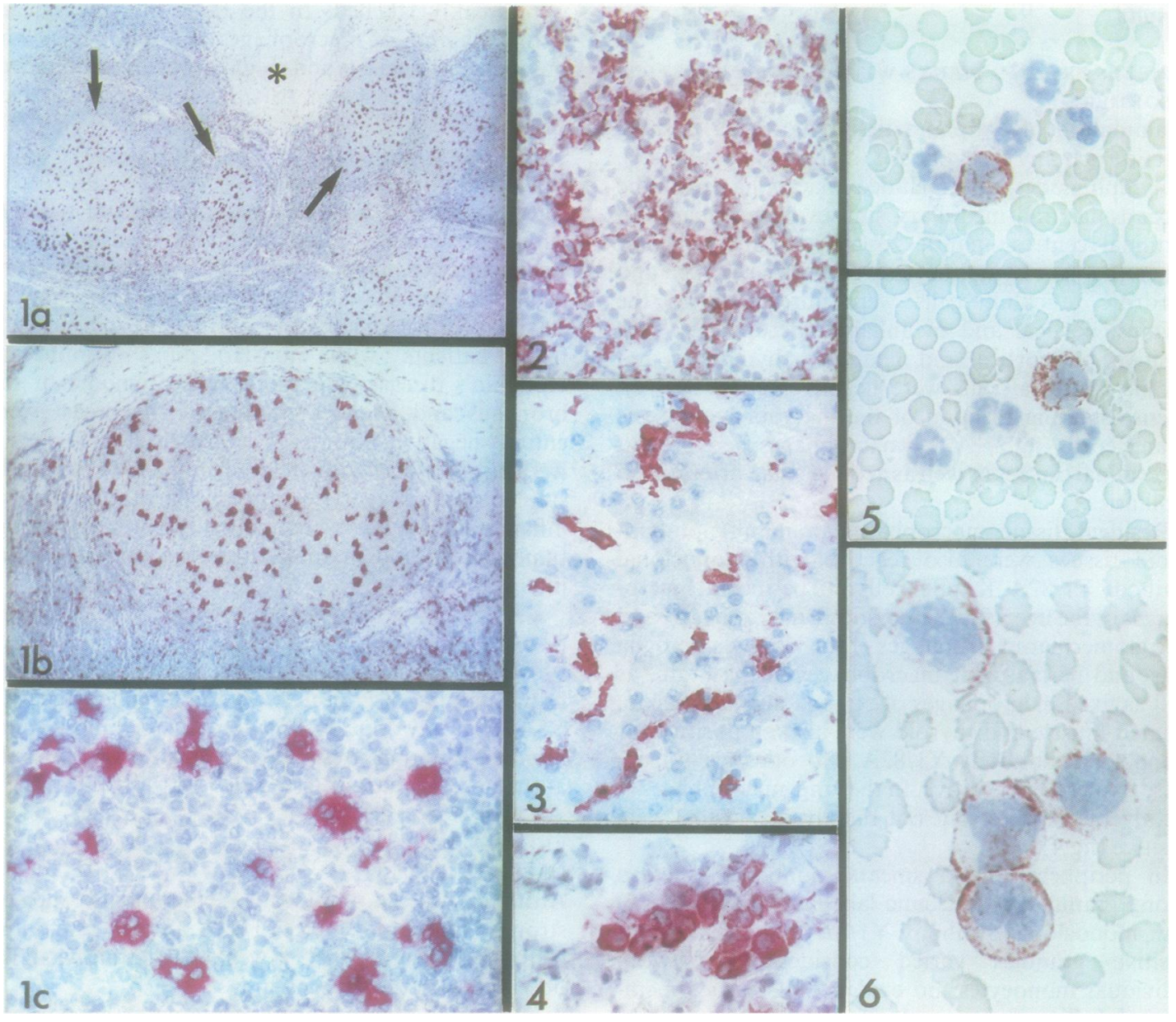

Fig 1 APAAP staining of reactive lymph node (cryostat section) with antibody $Y 1 / 82 A$. (a) Low power view shows $B$ cell follicles (arrowed) containing Y1/82A positive germinal centre macrophages. (b) Higher power view of $B$ cell follicle. Note scattered Y1/82A positive cells in extrafollicular tissue (T cell area). (c) High power view showing YI/82A positive germinal centre macrophages.

Fig 2 APAAP staining of human spleen (cryostat section) showing strong Y1/82A positive staining of macrophages in splenic cords (contrasting with unstained splenic sinusoids).

Fig 3 APAAP staining of human liver (cryostat section) with antibody Y1/82A showing intense staining of Kupffer cells, but not of hepatocytes.

Fig 4 APAAP staining of human lung (cryostat section) showing Y1/82A positive alveolar macrophages.

Fig 5 APAAP stained peripheral blood smear showing two Y1/82A positive monocytes, contrasting with unstained neutrophils and red cells.

Fig 6 APAAP staining of peripheral blood from patient with acute myelomonocytic leukaemia showing strong positive labelling of leukaemic cells with antibody Y1/82A. 
Table 2 Distribution of $Y 1 / 82 \mathrm{~A}$ antigen in peripheral blood and tissues from patients with neoplastic disorders

\begin{tabular}{ll}
\hline Type of neoplasm & $\begin{array}{c}\text { Labelling with monoclonal antibody } \\
Y 1 / 82 \mathrm{~A}\end{array}$ \\
\hline $\begin{array}{l}\text { Acute myelomonocytic } \\
\text { leukaemia }\end{array}$ & Leukaemic blasts \\
$\begin{array}{l}\text { Acute monocytic leukaemia Leukaemic blasts } \\
\text { Non-Hodgkin's lymphoma }\end{array}$ & $\begin{array}{l}\text { Tissue macrophages associated with } \\
\text { groups of neoplastic lymphoid cells }\end{array}$ \\
Hodgkin's lymphoma & $\begin{array}{l}\text { Sinus macrophages, germinal centre } \\
\text { macrophages, T zone macrophages }\end{array}$ \\
$\begin{array}{l}\text { Squamous cell carcinoma } \\
\text { of bronchus }\end{array}$ & $\begin{array}{c}\text { Tissue macrophages near groups of } \\
\text { neoplastic epithelial cells }\end{array}$ \\
$\begin{array}{l}\text { Adenocarcinoma of breast } \\
\text { Tissue macrophages near groups of } \\
\text { neoplastic epithelial cells }\end{array}$ \\
\hline
\end{tabular}

monocyte-macrophage system and those of the lymphoid and granulocytic series. Lymphocytes in the peripheral blood and in a range of lymphoid tissues showed no reactivity with $\mathrm{Y} 1 / 82 \mathrm{~A}$. The antibody was also unreactive with any epithelial, endothelial, or other mesenchymal cells with the exception of osteoclasts and megakaryocytes. Cells of the granulocytic series were usually unlabelled, although the inconsistent staining of some neutrophils, occasionally observed in blood films, requires further investigation (it may conceivably represent the presence of the antigen in a masked form).

Interestingly, $\mathrm{Y} 1 / 82 \mathrm{~A}$ reacts with osteoclasts as there is evidence that these cells may be developmentally related to cells of the monocyte-macrophage system. Studies in mice and in man have shown that osteopetrosis, a disorder secondary to a failure of osteoclastic function, is cured by an infusion of stem cells through bone marrow transplantation..$^{24} 25$ Some macrophage monoclonal antibodies fail to bind to human osteoclasts ${ }^{26}$; others give strong reactions of this sort. ${ }^{27}$ Further studies are therefore required to establish the clinical importance of these observations to the hypothesis of a developmental association between osteoclasts and cells of the monocytemacrophage system.

This study shows that the Y1/82A antigen is also present on megakaryocytes. Previous studies ${ }^{3}$ have indicated that monocytes and megakaryocytes arise from multipotential stem cells capable of differentiation into cells of the erythrocytic, granulocytic, macrophage and megakaryocytic series. There are probably many constituents which are shared among cells from the megakaryocytic and monocyticmacrophage systems, and the Y1/82A determinant is probably one such shared antigen.

Y1/82A reacts with cells of the monocyte-macrophage system in a pattern of distribution similar to a number of other previously described monoclonal antibodies: EMB1 $1,{ }^{10} 24,{ }^{13} 3 \cdot 9,{ }^{28} \mathrm{~KB} 90,{ }^{29}$ and $\mathrm{Ki}-\mathrm{M} 6 .{ }^{30}$ These five monoclonal antibodies react with peripheral blood monocytes and tissue macrophages in most organs of the body, but major differences exist between them and Y1/82A. Monoclonal antibody 24 binds to a 174000 dalton determinant on the surface of monocytes and tissue macrophages, ${ }^{13}$ the other five monoclonal antibodies react predominantly with cytoplasmic antigens. Monoclonal antibodies 3.9 and KB90 recognise the p150/95 (CD11c) leucocyte differentiation antigen ${ }^{28} 29$ present in peripheral blood monocytes, tissue macrophages and a subpopulation of neutrophils. Monoclonal antibody EBM $11^{10}$ reacts against a cytoplasmic determinant of undefined molecular weight and binds to Langerhans' cells as well as proximal tubular epithelial cells. This labelling pattern of monoclonal antibody EBM11 separates it from monoclonal antibodies $\mathrm{Ki}-\mathrm{M} 6$ and $\mathrm{Y} 1 / 82 \mathrm{~A}$ which do not label Langerhans' cells nor proximal tubular epithelial cells.

The monoclonal antibody that most closely resembles $\mathrm{Y} 1 / 82 \mathrm{~A}$ is $\mathrm{Ki}-\mathrm{M} 6$, which binds to a cytoplasmic constituent with a molecular weight of $60000 \mathrm{Kd}$ and which was detected by Western blotting. ${ }^{30}$ Both of these monoclonal antibodies label similar cells in the peripheral blood, bone marrow, and other tissues of the body. Conclusions regarding the relation between monoclonal antibodies $\mathrm{Ki}-\mathrm{M} 6$ and Y1/82A, however, require further studies entailing metabolic labelling and immunoprecipitation.

Y1/82A reacts intensely with leukaemic cells from patients with acute myelomonocytic leukaemia and acute monocytic leukaemia and could probably help identify subtypes of acute myeloid leukaemia (FABM4 and M5 as described by the French-AmericanBritish international study group), ${ }^{31}$ which tend to respond less well to treatment and have a poor prognosis. ${ }^{32}$

Y1/82A vividly shows the large number of tissue macrophages that are associated with neoplastic cells. This is particularly evident in the non-Hodgkin's and Hodgkin's lymphomas. It is possible that these tissue macrophages are acting against the tumour cells in some way on behalf of the host, but the mechanisms are as yet poorly understood. Although some recent studies with lectins and monoclonal antibodies have shown antigenic similarities between Reed-Sternberg cells and cells of the monocyte-macrophage system, ${ }^{33-35}$ our study suggests that the Y1/82A antigens are not present on Reed-Sternberg cells. This supports the view of other workers who suggest that Reed-Sternberg cells are derived from cells not part of the monocyte-macrophage system..$^{3637}$

In conclusion, we have described a new monoclonal antibody, Y1/82A, which reacts with peripheral blood and bone marrow monocytes and resident macrophages of essentially all tissues of the body. Y1/82A does not seem to bind to either lymphocytes or to dendritic reticulum cells. It reacts with osteoclasts and megakaryocytes suggestive of a common lineage with these various cell types. Furthermore, Y1/82A reacts with leukaemic cells from patients with acute myelomonocytic leukaemia and acute monocytic leukaemia. It is evident that $Y 1 / 82 \mathrm{~A}$ may be of considerable practical importance in the delineation of 
monocytic leukaemias and histiocytic malignancies.

This work was supported by grants from the Leukaemia Research Fund. KCG is a Wellcome Senior Research Fellow in clinical service.

\section{References}

1 Cline MJ, Lehrer RI, Territo MC, Golde DW. Monocytes and macrophages: Functions and diseases. Ann Intern Med 1978;88:78-88.

2 Steinman RM, Nussenzweig MC. Dendritic cells: features and functions. Immunol Rev 1980;53:127-47.

3 Quesenberry P, Levitt L. Hematopoietic stem cells. N Engl J Med 1979;301:755-60,819-23,868-72.

4 Gale RP, Sparkes RS, Golde DW. Bone marrow origin of hepatic macrophages (Kupffer cells) in humans. Science 1978;201: 937-8.

5 Radzun HJ, Parwaresch MR. Differential immunohistochemical resolution of the human mononuclear phagocyte system. Cell Immunol 1983;82:174-83.

6 Zwadlo G, Brocker EB, von Bassewitz DB, Feige U, Sorg C. A monoclonal antibody to a differentiation antigen present on mature human macrophages and absent from monocytes. J Immunol 1985;134:1487-92.

7 Bainton DF, Golde DW. Differentiation of macrophages from normal human bone marrow in liquid culture. Electron microscopy and cytochemistry. J Clin Invest 1978;61:1555-69.

8 Hancock WW, Zola H, Atkins RC. Antigenic heterogeneity of human mononuclear phagocytes: Immunohistologic analysis using mononuclear antibodies. Blood 1983;62:1271-9.

9 Yam LT, Li CY, Crosby WH. Cytochemical identification of monocytes and granulocytes. Am J Clin Pathol 1971;55:283-90.

10 Franklin WA, Mason DY, Pulford K, et al. Immunohistological analysis of human mononuclear phagocytes and dendritic cells by using monoclonal antibodies. Lab Invest 1986;54:322-35.

11 Buckley PJ, Dickson SA, Walker WS. Tissue distribution of macrophage cell surface antigens in human spleen. Lab Invest 1984;50:8A.

12 Dimitriu-Bona A, Burmester GR, Waters SJ, Winchester RJ. Human mononuclear phagocytes differentiation antigens. I. Patterns of antigenic expression on the surface of human monocytes and macrophages defined by monoclonal antibodies. J Immunol 1983;130:145-52.

13 Hogg N, Selvendran Y. An anti-human monocyte/macrophage monoclonal antibody, reacting most strongly with macrophages in lymphoid tissue. Cell Immunol 1985;92:247-53.

14 Knowles DM II, Tolijain B, Marboe D, D'Agati V, Grimes M, Chess $\mathrm{L}$. Monoclonal antihuman monocyte antibodies OKMI and OKM5 possess distinctive tissue distributions including differential reactivity with vascular endothelium. J Immunol 1984;132:2170-3.

15 Raff HV, Picker LJ, Stobo JD. Macrophage heterogeneity in man. A subpopulation of HLA-DR-bearing macrophages required for antigen-induced $T$ cell activation contains stimulators for autologous-reactive T cells. J Exp Med 1980;152:581-93.

16 Erber WN, Mynheer LC, Mason DY. APAAP labelling of blood and bone marrow samples for phenotyping leukaemia. Lancet 1986;i:761-5.

17 Mason DY, Cordell JL, Pulford KAF. Production of monoclonal antibodies for immunocytochemical use. In: Bullock GR Petrusz P, eds. Techniques in immunocytochemistry. London: Academic Press, 1983:175.

18 Cordell JL, Falini B, Erber WN, et al. Immunoenzymatic labeling of monoclonal antibodies using immune complexes of alkaline phosphatase and monoclonal anti-alkaline phosphatase (APAAP complexes). J Histochem Cytochem 1984;32:219-29.

19 Mason DY, Erber WN, Falini B, Stein H, Gatter KC. Immunoenzymatic labelling of haematological samples with monoclonal antibodies. In: Beverley PCL, ed. Methods in hematology: monoclonal antibodies. Edinburgh: Churchill Livingstone, 1986:145-81.

20 Dalchau R, Fabre JW. The purification of antigens and other studies with monoclonal antibody affinity columns: the complementary new dimension of monoclonal antibodies. In: McMichael AJ, Fabre JW, eds. Monoclonal antibodies in clinical medicine. London: Academic Press, 1982:519-56.

21 Laemli UK. Clearage of structural proteins during the assembly of the head of bacteriophage T4. Nature 1970;227:680-5.

22 Towbin H, Staehelin T, Gordon J. Electrophoretic transfer of proteins from polyacrylamide gels to nitrocellulose sheets: Procedure and some applications. Proc Natl Acad Sci USA 1979;76:4350-4.

23 Woodcock-Mitchell J, Eichner R, Nelson WG, Sun TT. Immunolocalization of keratin polypeptides in human epidermis using monoclonal antibodies. J Cell Biol 1982;95:580-8.

24 Coccia PF, Krivit W, Cervenka J, et al. Successful bone marrow transplantation for infantile malignant osteopetrosis. $N$ Engl J Med 1980;302:701-8.

25 Walker DG. Control of bone marrow resorption by hematopoietic tissue. The induction and reversal of congenital osteopetrosis in mice through use of bone marrow and splenic transplants. $J$ Exp Med 1975; 142:651-63.

26 Horton MA, Lewis D, McNulty K, Pringle JAS, Chambers TJ. Monoclonal antibodies to osteoclastomas (giant cell bone tumors): definition of osteoclast-specific cellular antigens. Cancer Res 1985;45:5663-9.

27 Athanasou NA, Heryet A, Quinn J, Gatter KC, Mason DY, McGee JOD. Osteoclasts contain macrophage and megakaryocyte antigens. J Pathol 1986;150:239-46.

28 Hogg N, Takas L, Palmer DG, Selvendran Y, Allan C. The p150,95 molecule is a marker of human mononuclear phagocytes: Comparison with expression of class II molecules. Eur J Immunol 1986;16:240-8.

29 MacDonald SM, Pulford K, Falini B, Micklem K, Mason DY. A monoclonal antibody recognizing the p150/95 leucocyte differentiation antigen. Immunol 1986;59:427-31.

30 Parwaresch MR, Radzun HJ, Kreipe H, Hansmann ML, Barth J. Monocyte/macrophage-reactive monoclonal antibody Ki-M6 recognizes an intracytoplasmic antigen. $A m J$ Pathol 1986;124:141-51.

31 Bennett JM, Catovsky D, Daniel MT, et al. Proposals for the classification of the acute leukaemias. $\mathrm{Br} J$ Haematol 1976;33:451-8.

32 Griffin JD, Davis R, Nelson DA, et al. Use of surface marker analysis to predict outcome of adult acute myeloblastic leukemia. Blood 1986;68:1232-41.

33 Hsu SM, Jaffe ES. Leu M1 and peanut agglutinin stain in the neoplastic cells of Hodgkin's disease. Am J Clin Pathol 1984;82:29-32.

34 Hsu SM, Yang K, Jaffe ES. Phenotypic expression of Hodgkin's and Reed-Sternberg cells in Hodgkin's disease. Am J Pathol 1985;118:209-17.

35 Strauchen JA. Lectin receptors as markers of lymphoma cells. II. Reed-Sternberg cells share lectin-binding properties of monocyte macrophages. Am J Pathol 1984;116:370-6.

36 Stein H, Mason DY, Gerdes J, et al. The expression of Hodgkin's disease associated antigen $\mathrm{Ki}-\mathrm{l}$ in reactive and neoplastic lymphoid tissue: Evidence that Reed-Sternberg cells and histiocytic malignancies are derived from activated lymphoid cells and histiocytic malignancies are derived from activated lymphoid cells. Blood 1985;66:848-58.

37 Strauchen JA, Dimitriu-Bona A. Immunopathology of Hodgkin's disease. Characterization of Reed-Sternberg cells with monoclonal antibodies. Am J Pathol 1986;123:293-300.

Requests for reprints to: Dr F R Davey, Division of Clinical Pathology, SUNY Health Science Center, 750 East Adams Street, Syracuse, New York, 13210, USA. 